\title{
The Impact of Concurrent Engineering Strategy on New Compex Product Development Process in Organization: An Empirical Study of Manufacturing and Service Industry in Malaysia
}

\author{
Amran Rasli ${ }^{\mathrm{a}^{*}}$, Saif ur Rehman Khan ${ }^{\mathrm{a}}$, Tan Owee Kowang ${ }^{\mathrm{a}}$ \\ ${ }^{a}$ Faculty of Management, Universiti Teknologi Malaysia, 81310 UTM Johor Bahru, Johor, Malaysia
}

*Corresponding author: m-amran@utm.my

\section{Article history}

Received :23 May 2012

Received in revised form : 28

February 2013

Accepted : 6 March 2013

\begin{abstract}
Taking into account the customers, supplier and organization involvement in the new product development (NPD), this article focuses on the synthesis, evaluation, and selection of various sub-factors of concurrent engineering involved in new product development process. The aim of this study was to provide the reliability and validity of six sub-factors of concurrent engineering model of the 49-item questionnaire and to analyze its association with concurrent engineering and new product development process in a sample of 35 manufacturing and services organization located in Johor, Malaysia. Methods: A self reported survey was conducted in 35 manufacturing and services organization located in Johor, Malaysia. Results: Appropriate internal consistencies of the six sub-scales: customers relationship, team development, continuity, tools and techniques, suppliers involvement and corporate focus and their association with concurrent engineering, were obtained. Zero-order correlation and regressions analysis replicated the theoretically assumed structure of the effective concurrent engineering (ECE). Evidence of criterion validity was obtained from cross-correlations of the scales and from their linear and multiple regression analysis. Finally, all seven scales were associated with a highly significant ratio of concurrent engineering as predicted by fundamental theory. Conclusion: Based on the results of this study the seven version of the model, questionnaire is considered a reliable and valid instrument for measuring association in developing the new complex product development process.
\end{abstract}

Keywords: Concurrent engineering; new product development; customer satisfaction

\section{Abstrak}

Mengambil kira penglibatan pelanggan, pembekal dan organisasi dalam pembangunan produk baru (NPD), artikel ini memberi tumpuan kepada sintesis, penilaian, dan pemilihan pelbagai sub-faktor kejuruteraan serentak yang terlibat dalam proses pembangunan produk baru. Tujuan kajian ini adalah untuk menyediakan kebolehpercayaan dan kesahan model enam sub-faktor kejuruteraan serentak melalui soal selidik dan untuk menganalisis hubungan antara kejuruteraan serentak dengan pembangunan produk baru. Kaedah: Kajian kuantitatif melibatkan 35 organisasi pembuatan and perkhidmatan yang terletak di Johor, Malaysia. Keputusan: Ketekalan dalaman yang bersesuian antara keenam-enam sub-faktor, iaitu hubungan pelanggan, pembangunan pasukan, kesinambungan pasukan, penggunaan alat dan teknik, penglibatan pembekal dan tumpuan korporat serta hubuganan mereka dengan kejuruteraan serentak telah diperolehi. Analisis korelasi sifar dan analisis regresi telah replika struktur teori keberkesanan kejuruteraan serentak (ECE) seperti yang diandaikan. Bukti kesahan kriteria telah diperolehi daripada korelasi silang skala dan dari analisis regresi linear. Akhirnya, kesemua tujuh sub-fakor telah dikaitkan dengan nisbah yang amat ketara dengan kejuruteraan serentak seperti yang diramalkan oleh teori asas. Kesimpulan: Berdasarkan keputusan kajian ini, soal selidik dianggap sebagai instrumen yang boleh dipercayai dan sah untuk mengukur hubungan antara proses yang kompleks dalam pembanguan produk baru.

Kata kunci: Kejuruteraan serentak; pembagunanan produk baru; kepuasan pelanggan 


\subsection{INTRODUCTION}

Studies of an organization's effectiveness have been at the heart of organizational theory for many years. However, measurements of New Product Development (NPD) effectiveness have been slow to converge to a standard or even an accepted operative framework (Shenhar, 2002). Prior research has shown that NPD performance measurements or indicators can effectively distinguish best practice R\&D firms from average Research and Development (R\&D) industries (Cooper and Edgett 2008, Hauser, Tellis, and Griffin 2006). However, many of the NPD performance variables focus on factors outside the R\&D barrier (Han, 2003). Most of the NPD performance indicators concentrate on measurements of financial gains and market response of the new products, and lack of emphasis on indicators that measure the effectiveness of NPD process prior to product launch (Cooper and Edgett 2008; Ledwith and O'Dwyer, 2009). An effective NPD process is the key impact factor in an organization's ability to develop and manage innovation (Marisa et. al., 2008). Competitive and hostile business environments make an effective NPD process more important to business to ensure that the business stays ahead of present or potential competition (Michael, 2008). Hence, this research reviews the types of NPD performance measurements as suggested by prior researchers (Shenhar, 2002; Han, 2003, Cooper and Edgett 2008; Ledwith and O'Dwyer, 2009), follows by proposal of methodology on NPD effectiveness measures and prediction of NPD performance prior to product launch. Research on product development indicates that design-manufacturing integration (DMI) accelerates the NPD process by involving manufacturing at an early stage of innovation and has positive impact on cost, quality and performance (Rusinko, 1999). "DMI practices are positively related to effective NPD for new products, but not for product enhancement" (Rusinko, 1999). DMI is defined as "a specific application of cross-functional coordination that enforces coordinating interdependence and managing innovation between design and manufacturing". DMI includes downstream product development methods during the upstream phases of NPD process. So, conceptually DMI mean any product manufacturing tool that include concurrent engineering (CE), simultaneous engineering, and design for manufacturability (DFM). Concurrent engineering can be a good example of parallel processing that reduces the product development time and achieves transition from product design to development (Gunasekaran, 1998; Hauptman and Hirji, 1999; Ainscough et al., 2003; Rusinko, 1999; Liker et al., 1999; Boyle et al., 2003).

This research focuses on the assessment of the perception of NPD effectiveness and prediction of NPD performance prior to product launch in a multi location $R \& D$ company where the one author works as Head of Engineering in the Malaysia branch. The company under examination enjoys a high reputation for extensive research and development activities. The Head Office of this company is located in the United Kingdom and it maintains operations in Malaysia, USA, Europe, Australia, Japan, China and Singapore. As a R\&D based company, its survival in a competitive market depends on the success of its $R \& D$ operation. $R \& D$ excellence in the company refers to the delivery of new products which are on time, on cost and meet product reliability targets. However, for the company to remain competitive and continue with sustainable growth, effective management in the respective multi location $R \& D$ facilities is not the only challenge. Continuous improvement in NPD processes are another concern, including improvements such as reduced product development lead time, reduced product costs and enhancements in product reliability performance. According to Birinshaw and Fibson (2004), an ideal NPD process framework should be able to deal with incremental innovation in short term, and revolutionary innovation in longer term. Therefore, to build up the organization capability to accommodate both incrementally and revolutionary innovation, in the formation of NPD process framework, organization should focus on framework that promotes incremental innovation and at the same time maintain a systematic process structure. The NPD process framework used by the company under study is a recursive based NPD framework that promotes concurrent engineering (CE) activities and multiple feedback loops across all NPD phases. CE refers to the bringing of the design and manufacturing engineers together early in the design phase to simultaneously develop the product and processes for producing the product (Stevenson, 1999). The basic concept of $\mathrm{CE}$ is to take the product design process out of the isolated world of design engineers and incorporate the other functional requirements that have, or should have, influence over the design (Farrington and Martin, 1994). CE promotes early involvement of a cross-functional team to simultaneously plan product, process and manufacturing (Hartley,1998) which will be manifested through concurrent work-flows, product development team and early involvement of constituents (Koufterous, 2001). Zhang, Anthony and Scott (2009) described NPD performance as the market reward for new products in terms of the products' contributions to sales and profits. The description of NPD performance by Zhang, Anthony and Scott (2009) is in line with a definition from PMDA (Product Management and Development Association, USA). Based on PMDA, NPD performance indicators are the criteria in which the performances of new products in the market are evaluated. Smith (1998) and Lioukas (2007) revealed that the main driver for NPD performance is an effective NPD process. According to Smith (1998), an efficient NPD process will result in a reduction in the amount of time consumed from idea formulation to product launch. Contributing factors include capturing customer preference at an early stage, reducing costs by avoiding redesign, increasing information exchange between functional teams and increasing product performance through the incorporation of features that satisfy customer needs. This definition is reinforced by Lioukas (2007) who defined NPD performance as a means to reduce the time required to introduce the product to the market, the maximization of product quality, the maximization of productivity and improved response to customer needs. An exploratory field study done by Han (2003) on seventy four technology-oriented $R \& D$ project teams suggested that many of the NPD performance variables are focused outside the R\&D barrier. The study identified forty four typical NPD Performance Indicators that are commonly used in R\&D organizations. From the forty four common NPD Performance Indicators, Han (2003) identified the two most frequently cited categories. The first category is NPD performance indicators for R\&D organization as a whole, and the second category is NPD performance measures of NPD teams and individuals. From the Han (2003) study, the most frequently cited NPD performance indicator for $R \& D$ organizations as a whole are:

(a) Number of new products introduced to market per year.

(b) Time-to-market, which can be described as the length of time taken to develop a new product from an early 
initial idea to initial market sales. Precise definitions of the start and end point vary from one company to another, and may vary from one project to another within the company.

(c) Cost and performance improvements on new products versus preceding products.

(d) Patent disclosure or number of patent applications which originate from the new products.

An assessment of individual and R\&D teams' contribution toward NPD performance is very difficult, and often impossible to obtain with any degree of confidence (Hans, 2003). In addition, some of these measurements, such as "Effort and commitment to established objectives" and "Judgment of innovative performance improvement" are very difficult to quantify. Therefore, organization or profit center based performance assessment is still the preferred NPD Performance Indicator. In studying what distinguishes top performer R\&D firms from average R\&D businesses, Cooper and Edgett (2008) make use of the following organization level NPD performance measurements to benchmark NPD performance of best practice R\&D firms with average R\&D business.

(a) Percentage of revenues and profits gained by the business from new products.

The percentage of revenues and profits from new products are both financial performance measures. From the Cooper and Edgett (2008) study, the most popular NPD performance measurement used by the 105 businesses which participated in the survey was "Percentage of sales revenue derived from new products."

(b) Success and failure rates of new products.

Success and failure rates are other key NPD performances measurements suggested by Cooper and Edgett (2008). They further suggested that NPD success and failure rate refer to the proportion of NPD projects entering the Development stage that become commercial successes by meeting or exceeding financial standards (for success rate), or become commercial failures (for failure rate).

(c) On Time and On Budget:

On time and on budget are both project management related performance measures, which are the proportion of NPD projects hitting their launch dates on time and on budget. "Slip rate" is the performance measurement for "on time", which measures how late a project is as a percentage of its total scheduled time to market. Similarly, measurements for "on budget" measure the percentage of actual project expenses versus budgeted or allocated amounts.

(d) NPD Projects Meeting Objectives

Cooper and Edgett (2008) defined NPD Project Objective as profit objectives and sales objectives, which are management performance related measures for NPD. The NPD performance indicators suggested by Cooper and Edgett (2008) embraced financial, commercial, project management and marketing aspects. However, new product quality related performance measures, as well as customer satisfaction or acceptance measures, are not considered as NPD performance measures in the study. In the research of evaluating the relationship between organization performance and NDP performance, Ledwith and O'Dwyer (2009) identified 17 measures to determine NPD performance. The 17 measures are grouped into five categories: 1) Market level measures; 2) Financial measures; 3) Customer acceptance measures; 4) Productlevel measure; and 5) Timing measure.

Ledwith and O'Dwyer (2009) used a seven point Likertscale to determine the NPD performance of 106 small firms in Ireland. Findings from the study revealed that out of 17 indicators, four scored significantly higher application rates than the others. Of these four, two are product-level measures, which are 1) Met Performance Specification, 2) Met Quality Specification and two are customer-acceptance measures, which are 1) Customer Satisfaction and 2) Customer Acceptance. The finding supports an earlier study by Brown et al. (2004), who found that these were common new product performance measures used by small firms. So, companies should assess their product strategy continuously and redefine product architecture, platforms, modularization, and standardization. Redefining product strategy has an influence on Customers' relationship, team development, team continuity, tools and techniques, suppliers' involvement and corporate focus. Also, product structure has impact on product development performance by influencing time, cost, product quality, and variety (Muffatto and Roveda, 2002). The product architecture shows the functional and physical components of a product and stipulates the specification of interfaces between these interactive physical components. Product architecture is related to the innovation process at beginning stage as the architectural decisions are linked to specific issues such as ease of product change, the division between internal and external development resources, technical product performance, and organization and management of the development process" (Ulrich, 1995).

Also, the literature focuses application of product manufacturing tools such as concurrent engineering, and project mapping techniques to a same single product or product family (Ulrich, 1995; Rusinko, 1999; Schilling and Hill, 1998). But, the objective of product development tools like CE is to optimize cost, quality, and lead-time of new product introduction (Gunasekaran, 1998; Ainscough et al., 2003). And these were the reasons why project management tactics were used in product development (Cicmil, 1997; Kerzner, 2003). Thus, an investigative probe is to find out the common platform for $\mathrm{CE}$ and project management that focus mainly on the framework proposed by Kumar et al. (2003) for developing new complex product and the self-assessment model (Ainscough et al., 2003) that takes help from concurrent engineering to manufacture new products. London Taxis International of U.K implemented the self-assessment model. It explains six practice components of CE namely; New Product Introduction (NPI) process, teamwork, information technology, tools and techniques, supply chain management and project management1. Kumar et al.'s (2003) NPD framework for complex defense products explains how effectively and efficiently NPD uses project management tointegrate both internal sources and external sources to develop technologically complex systems.

\subsection{THEORETICAL FRAMEWORK OF STUDY}

The six sub-factors of concurrent engineering identified in introduction sections were integrated with NPD performance to form a framework using the factor approach. The factor approach is favored over the process approach so as to better understanding the relationship between causes and effects. 
Within the context of this study, the causes are the six main CE construct, while the effect is efficient NPD through CE process. In factor theories, these constructs are usually conceptualized as variables, i.e., entities which can take on a range of values (Malhotra, 1997).

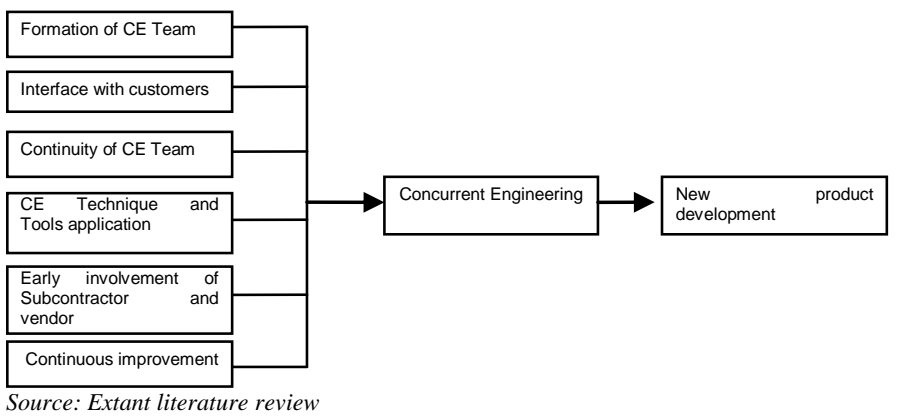

Figure 1 Factor model for efficient NPD through CE process

\subsection{RESEARCH QUESTIONS}

To identify the impact of concurrent engineering strategy on new product development process in manufacturing and services organizations, we focused the following main research questions adapted from past studies. The main questions were:

Q1. What factors of CE are the main issues in your new product development?

Q2. What are the main factors that contribute significantly to NPD?

Q3. At what time and under what circumstances sub-factors of CE affect most on NPD process?

Q3. Does control over various factors of $\mathrm{CE}$ affect on the magnitude of NPD process?

Q4. What are the prominent factors of CE in NPD process in your organization?

\subsection{RESEARCH METHOD}

\subsection{Participants and Procedure}

This research applies quantitative survey to assess importance level and implementation level of $\mathrm{CE}$ in the multi location Research and Development (R\&D) companies. Quantitative survey was used because, according to Blanche, Durrheim and Painter (2006), quantitative research brings more generalize findings as compared to qualitative approach.

Most of the studies of management use survey method to collect data. Same method was used in the present study a total of 120 questionnaires were distributed, out of which 98 responded back (response rate $81.6 \%$ ). survey questionnaire incorporates seven CE constructs, the 49 attributes and the 3 NPD performances measures which were summarized from the literature review. In the questionnaire, the respondents were asked to rate the level of CE implementation in NPD process by rating each of the 49 statements on a five point scale ranging from (1) no implementation to (5) full implementation, followed by rating of the importance level of each of the 49 statements on a five point scale ranging from (1) not important to (5) extremely important. In additional, the respondents were also asked to rate the level of NPD performance by rating the 3 performance measures from (1) Very low to (5) very high. The perception of the importance level and implementation level of the $49 \mathrm{CE}$ attributes were used to identify the implementation effectiveness of the CE in NPD and subsequently to predict NPD performance. The total population for this research is 210 respondents (consists of personnel involved in studying role of concurrent engineering in NPD activities in consideration of design engineers, technical development engineers, test engineer, tooling engineers, quality engineers and commercial executives).

\subsection{DATA ANALYSIS AND RESULTS}

5.1 Tests of Concurrent Engineering and New Product Development Hypotheses Correlation Analyses

Table 1 shows the zero-order correlations between the total subfactors of concurrent engineering and new product development process. The six sub factors of concurrent engineering variables were highly correlated (see tables) with effective concurrent engineering. Corporate focus, team continuity and tools and techniques are high positively and significantly related to concurrent engineering, whilst team development and suppliers' involvement are also positively (and slightly less significant) related to concurrent engineering. Furthermore, the relative magnitude of these bi-variate correlations is consistent with original predictions

Table 1 Correlation matrix

\begin{tabular}{|c|c|c|c|c|c|c|c|c|}
\hline \multicolumn{9}{|c|}{ Time Variables } \\
\hline ن气 & 홍 & 1 & 2 & 3 & 4 & $\mathbf{5}$ & 6 & 7 \\
\hline 1 & $\begin{array}{l}\text { Formation of } \\
\text { CE teams }\end{array}$ & $(.85)$ & & & & & & \\
\hline 2 & $\begin{array}{l}\text { Interface } \\
\text { with } \\
\text { customers }\end{array}$ & .83 & $(.89)$ & & & & & \\
\hline 3 & $\begin{array}{l}\text { Continuity } \\
\text { of CE teams } \\
C E\end{array}$ & .76 & .87 & (.87) & & & & \\
\hline 4 & $\begin{array}{l}\text { technique } \\
\text { and tools } \\
\text { application } \\
\text { Early } \\
\text { involvement }\end{array}$ & .72 & .77 & .72 & $(.88)$ & & & \\
\hline 5 & $\begin{array}{l}\text { of sub } \\
\text { contractor } \\
\text { and vendors }\end{array}$ & .69 & .71 & .69 & .83 & $(.90)$ & & \\
\hline 6 & $\begin{array}{l}\text { Continuous } \\
\text { improvement }\end{array}$ & .64 & .69 & .64 & .81 & .79 & $(.90)$ & \\
\hline 7 & $\begin{array}{l}\text { Concurrent } \\
\text { Engineering }\end{array}$ & .81 & .83 & .76 & .86 & .84 & .78 & (.88) \\
\hline
\end{tabular}

\subsection{Linear and Multiple Regression Analyses}

Table 2 shows that six sub-factors of concurrent engineering were explained significant amount of the variance in new product development and concurrent engineering. These variances were analyzed as under: 
Table 2 Hierarchical regression analyses of job factors scales upon job predictors of model and their interactions (main effect)

\begin{tabular}{|c|c|c|c|c|c|c|c|}
\hline Independent & Dependent & $\boldsymbol{\beta}$ & $\operatorname{se} \beta$ & Beta & $\begin{array}{l}\text { t- } \\
\text { Values }\end{array}$ & $\begin{array}{l}\mathbf{R}^{2} \\
\text { (Adjusted) }\end{array}$ & $\begin{array}{l}\text { F- } \\
\text { Values }\end{array}$ \\
\hline $\begin{array}{l}\text { Customers } \\
\text { Involvement }\end{array}$ & ECE & .63 & .043 & .83 & 14.62 & .68 & 213 \\
\hline $\begin{array}{l}\text { SKA of CE } \\
\text { Team }\end{array}$ & ECE & .60 & .051 & .76 & 11.76 & .58 & 139 \\
\hline $\begin{array}{l}\text { Consistency } \\
\text { of CE team }\end{array}$ & ECE & .79 & .046 & .86 & 17.20 & .75 & 295 \\
\hline ATT & ECE & 1.02 & .068 & .84 & 15.23 & .70 & 231 \\
\hline $\begin{array}{l}\text { Suppliers } \\
\text { Involvement }\end{array}$ & ECE & .58 & .047 & .78 & 12.48 & .61 & 155 \\
\hline $\begin{array}{l}\text { Corporate } \\
\text { Focus }\end{array}$ & ECE & .53 & .039 & .81 & 13.89 & .66 & 192 \\
\hline
\end{tabular}

Table 1, 2, 3 and 4 show that the main affects of six subfactors explained significant amount of the variances in effective concurrent engineering variables than with additive and quadratic effects. All factors were significant at the $\mathrm{p}<.001$ level, with additive and quadratic effects contributing less significantly to concurrent engineering variables. However, our findings in sub-factors of concurrent engineering variables were strongly significant and consistent to new product development variables. Specifically, there was a significant enhancing main effect for the various factors interaction in the basic model ( $\mathrm{p}<$ .001 ), than that of additive effects. Furthermore, the additive affect of customers' involvement and team consistency, customers' involvement and AAT were highly significantly associated with effective concurrent engineering variables.

In our analysis, $\mathrm{R}^{2}$ changes for six factors were remained significant at $p<.001$. Several points are noteworthy. Firstly, none of the main, additive and quadratic effects for various factors were non-significant, Secondly, main effects were highly significant than that of additive effect, and thirdly, all findings were consistent except main effect of customers' involvement and corporate focus variables which were slightly decline.

Several general other points are also noteworthy. Firstly, the specific factors explained a significant proportion of the variance in the concurrent engineering outcomes. Furthermore, the criterion of a reliable effect of customers' involvement, SKA of team, continuity of team and AAT were the highest predictors of concurrent engineering outcomes in our study of regression analyses.

\subsection{Modeling Analyses}

Two principal models were tested using PLS (partial least square). All models assumed that CE factors co-varied, customers' involvement, SKA of team, continuity of team, AAT, suppliers' involvement and corporate focus were the highest predictors of concurrent engineering outcomes co-varied and that there was significant interaction term with concurrent engineering and NPD process variables. The models also included covariance paths between the residuals in all endogenous variables specified at the same step in the hypothesized sequence.
Table 3 Hierarchical regression analyses of job factors scales upon job predictors of model and their interactions (additive)

\begin{tabular}{|c|c|c|c|c|c|c|c|}
\hline Dependent & Independent & $\beta$ & $S E \beta$ & Beta & $\begin{array}{l}\text { t- } \\
\text { Values }\end{array}$ & $\begin{array}{l}\mathbf{R}^{2} \\
\text { (Adjusted) }\end{array}$ & $\begin{array}{l}\text { F- } \\
\text { Values }\end{array}$ \\
\hline ECE & $\begin{array}{l}\text { Customers } \\
\text { Involvement } \\
\text { SKA of CE } \\
\text { Team }\end{array}$ & $\begin{array}{l}.51 \\
.14\end{array}$ & $\begin{array}{l}.088 \\
.092\end{array}$ & $\begin{array}{l}.673 \\
.180\end{array}$ & $\begin{array}{l}5.77 \\
1.54\end{array}$ & .69 & 109 \\
\hline ECE & $\begin{array}{l}\text { Customers } \\
\text { Involvement } \\
\text { Consistency } \\
\text { of CE team }\end{array}$ & $\begin{array}{l}.29 \\
.51\end{array}$ & $\begin{array}{l}.053 \\
.064\end{array}$ & $\begin{array}{l}.392 \\
.564\end{array}$ & $\begin{array}{l}5.58 \\
8.041\end{array}$ & .81 & 210 \\
\hline ECE & $\begin{array}{l}\text { Customers } \\
\text { Involvement } \\
\text { ATT }\end{array}$ & $\begin{array}{l}.35 \\
.61\end{array}$ & $\begin{array}{l}.048 \\
.078\end{array}$ & $\begin{array}{l}.468 \\
.505\end{array}$ & $\begin{array}{l}7.34 \\
7.91\end{array}$ & .80 & 206 \\
\hline ECE & $\begin{array}{l}\text { Customers } \\
\text { Involvement } \\
\text { Suppliers } \\
\text { Involvement }\end{array}$ & $\begin{array}{l}.41 \\
.30\end{array}$ & $\begin{array}{l}.051 \\
.050\end{array}$ & $\begin{array}{l}.55 \\
.40\end{array}$ & $\begin{array}{l}8.194 \\
6.066\end{array}$ & .77 & 165 \\
\hline ECE & $\begin{array}{l}\text { Customers } \\
\text { Involvement } \\
\text { Corporate } \\
\text { Focus }\end{array}$ & $\begin{array}{l}.388 \\
.229\end{array}$ & $\begin{array}{l}.106 \\
.092\end{array}$ & $\begin{array}{l}.512 \\
.347\end{array}$ & $\begin{array}{l}3.67 \\
2.49\end{array}$ & .70 & 115 \\
\hline
\end{tabular}

Table 4 Hierarchical regression analyses of job factors scales upon job predictors of model and their interactions (quadratic)

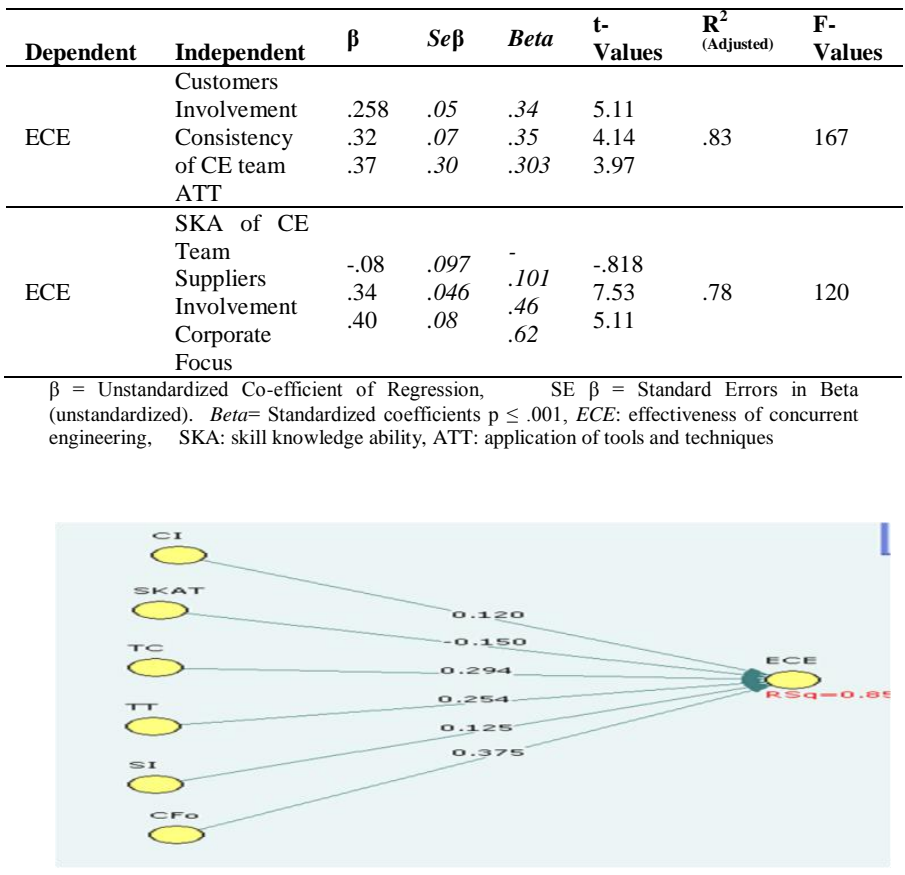

Model 1 Modified core model of concurrent engineering

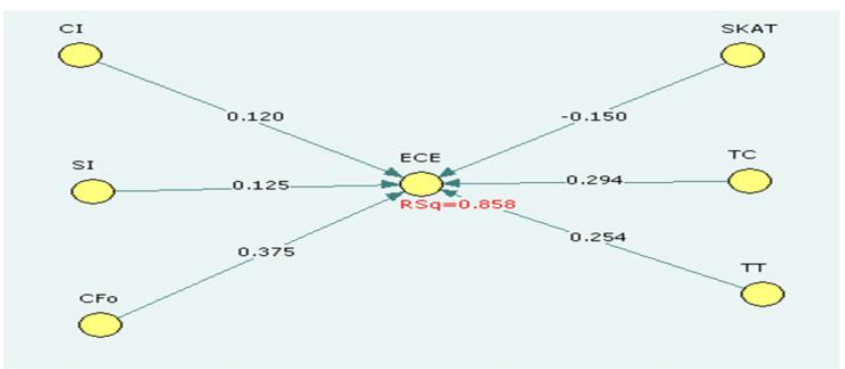

Model 2 Modified core model of concurrent engineering 


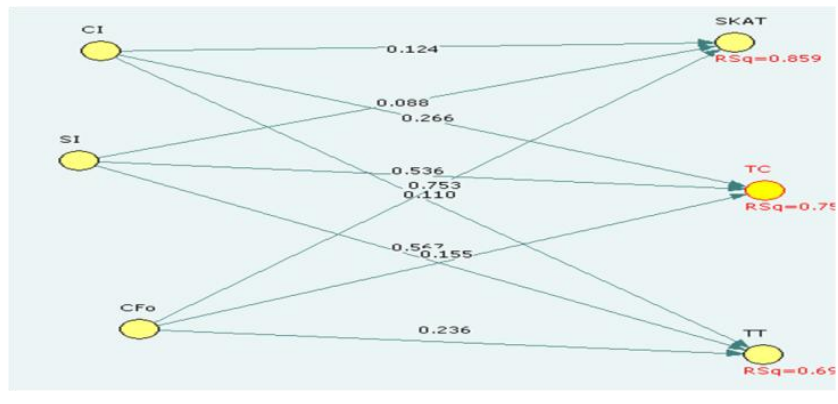

Model 3 Modified core model of concurrent engineering

\subsection{DISCUSSION \& CONCLUSION}

The essential element of the new product development is team work, so the article gives special significance to the development, structure and size of team in concurrent engineering (CE). Research has provided us the conclusion that a workgroups in $\mathrm{CE}$ should composed of six independent teams/groups. In spite of three variables teams (application of tools and techniques, continuity and SKA of team members) and that a three-level team structure (customers' involvement, suppliers' involvement, corporate focus) are more effective in CE. Researches on NPD performance, especially CE, on the importance of cross-functional integration (Liker et al., 1999) at the early stage of product design, are considered to be more importance. They further suggested that technical risk and uncertainty depends on the nature of innovation, nature of technology and effectiveness of concurrent engineering. Balachandran and Friar (1999) suggested the use of different strategies to mitigate technical risk and uncertainty for NPD projects that fall into different cells of their contextual model comprises of sub-factors (customers' involvement, SKA of team, continuity of team and AAT) involved in CE. They found out that an incremental innovation needs a more structured organizational factors, well-defined budgets, schedules and planning; whereas a effective concurrent engineering requires a more flexible approach. Thus, incremental innovation needs mechanistic organizations; whereas complex innovation needs organic organization. Mechanistic organizations are very efficient and effective and characterized by extensive rules and standardized procedures, strict chain of command, customers' involvement, suppliers' involvement, and corporate focus. Organic organizations are flexible and effective in rapidly changing environments, and characterized by few rules and standard procedures, broad role description, and horizontal communication (Liker et al., 1999). Subsystems of CE like customers' involvement, SKA of team, continuity of team and AAT fall into more than one cell of the contextual model. In fact, they covered the broad spectrum of CE/NPD. So, it was not surprising that the effective development of CE needed a hybrid organizational structure, which was a combination of both mechanistic and organic organizational structures. However, organizations seldom transfer themselves to an organizational structure that is effective to develop CE. This is the shortcoming in organizational structure which is complemented by use of NPD and CE. CE uses well-defined six methods, strict control/monitoring mechanism, vertical hierarchy and communication like the mechanistic organization. CE on the other hand is broad based, and is highly flexible. Its objective is to bring downstream $\mathrm{CE}$ processes such as manufacturability, testing, service, customer needs into the early stages of the NPD process within an organization. As focus of CE is on parallel work in multiple dimensions of developmental processes (Liker et al., 1999) it proves to be an effective tool in the rapidly changing environment of innovation; and also an effective substitute for an organic organizational structure. It was found in the $\mathrm{CE}$ developmental process. Also, the $\mathrm{CE}$ development, imposing well-defined procedures and methods, tight control/monitoring mechanism, vertical hierarchy corporate focus and communication between customers and suppliers (that of a "mechanistic" organization) through the formal control structure with NPD process occupies the top level and subsequent lower levels that is occupied by the prime and its sub-factors. CE basically acted as the integration and coordination force customers, suppliers and corporate management of organization. In this way; NPD and concurrent engineering complement one another. They both focus on customers' involvement, SKA of team; team continuity and AAT were the highest predictors of concurrent engineering outcomes.

This paper uses empirical research approach to show the links between sub-factors and $\mathrm{CE}$ for a complex product development. This research proves to be a good example of how NPD used concurrent engineering techniques effectively to integrate their internal and external resources for development of technologically complex systems. Although the NPD process for commercial products is absolutely different from the NPD process for defense products (Kumar et al., 2003), it is believed that this proposed framework can be applicable equally to complex product system development in commercial sectors such as manufacturing industry, services industries and electricity supply companies. It brings an insight for professional managers regarding new complex systems for product development, and so help them to manage their own CE capability as well as NPD capability by formulating proper technology they may have to outsource. It should be noted that this is an exploratory study which was conducted in the defense environment. Further study in a commercial environment is required to refine the framework or to develop a modified framework for NPD process of CE in general.

\subsection{FUTURE RESEARCH}

Future research could be conducted in other sectors which feature multi location R\&D such as semi-conductors, pharmaceuticals, as well as the food and medical industries. Different sectors of business might use a different approach to CE implementation. Research in other sectors will help to acquire a bigger overall picture of CE in NPD of multi location R\&D. In addition, studies in other firms involved in consumer products can also be carried out to compare and reinforce the findings discussed in this research. Future research could also look into the implementation framework towards achieving $\mathrm{CE}$ in $\mathrm{R} \& \mathrm{D}$ with the steps and processes modeled from this study. In addition, as an expansion of this research, future research could focus on the details of $\mathrm{CE}$ tools and techniques application, such as type of CE tools, application, and degrees of usefulness of CE tools on non-R\&D; co-located R\&D as well as multi location $R \& D$ organization. If the long term viability of $\mathrm{CE}$ depends on effectively developing and deploying CE tools, the assumptions about how CE design tasks are most successfully performed and the role of tools in facilitating that work should be carefully reviewed (King and Majchrzak, 1996). 


\section{References}

Ainscough, Matthew, Ncailcy, Kevin, and Tennant, Charles (2003). A self assessment tool for implementing concurrent engineering through change management. International Journal of Project Management. 21(1): 425-431.

Balachandran, R., and Friar, John H. 1999. Managing New Product Development Processes the Right Way. Information, Knowledge, Systems Management. 4(2):33-42.

Boyle, Todd A., Kumar, Uma, and Kumar, Vinod. 2003. Determinants of the Diffusion of Cross-functional New Product Development Teams. Proceedings of ASAC. 24(7):52-60.

Brown A., Soutar G.A. and Huang X. 2004. Measuring New Product Success: An Empirical Investigation of Australian SMEs. Industrial Marketing Management. 33(5):117-123.

Cicmil, Svetlana J. K. 1997. Perspectives Critical Factors of Effective Project Management. The TQM Magazine. 9(6): 390-396.

Cooper, R. G. and Edgett, S. 2008. Benchmarking Best Practices Performances Results and the Role of Senior Management. Product Management. 3(1): 1-6.

Farrington P. A. and Martin P. 1994. Paving Way for Concurrent Engineering. Industrial Engineering Journal. 1(1): 50-52.

Gunasekaran, A. 1998. Cuncurrent Engineering: A Competitive Strategy for Process Industries. Journal of the Operational Research Society. 49(1): $758-765$.

Hans, J. T. 2003. Managing Innovative R\&D Teams. Journal of $R \& D$ Management. 33(3): 297-311.

Hauptman, Oscar, and Hirji, Karim K. 1999. Managing Integration and Coordination in Crossfunctional Teams: An International Study of Concurrent Engineering Product Development. $R \& D$ Management. 29(2): 179-191.

Hauser, J., Tellis G. J. and Griffin, A. 2006. Research on innovation: A Review and Agenda for Marketing Science. Marketing Science. 25(6): 687-717.

Kerzner, H. 2003. Project Management: A Systems Approach to Planning, Scheduling, and Controlling. $8^{\text {th }}$ edition. John Wiley \& Sons, NJ. 222232.

King, N. and Majchzak, A. 1998. Concurrent Engineering Tools: Are the Human Issues Being Ignored. IEEE Transaction on Engineering Management. 43(2): 189-201.

Koufterous M. V. 2001. Concurrent Engineering and its Consequences. Journal of Operations Management. 19(1): 97-115.

Kumar, Vinod, Mathur, Sandeep and Kumar, Uma. 1994. An Overview of the Innovation Process in the Canadian Electronic and Telecommunication (E\&T) Industry. Engineering Management Journal. 6(3): 23-30

Ledwith, A. and O'Dwyer, M. 2009. Market Orientation, NPD Performance and Organization Performance in Small Firm. Journal of Product Innovation Management. 26(1): 652-661
Liker, Jeffery K., Collins, Paul D., and Hull, Frank M. 1999. Flexibility and Standardization:Test of a Contingency Model of Product DesignManufacturing Integration. Journal of Product Innovation Management. 16(1): 248-267.

Lioukas, S. 2007. Concurrent Engineering: Strategy for Effective Product Development Team to Achieve and Sustain Company's Objective. Harvard Business Review. 85(3): 94-102.

Malhotra Y. 1997. Process Models vs. Variance Models: What is the Difference? http://www.brint.com/wwwboard/messages/842.html, May, 1997.

Marisa, S., Marco, B., Peter, B. and Robert, V.D.M. 2008. Factors Influencing an Organization's Ability to Manage Innovation: A Structured Literature Review and Conceptual Model. International Journal of Innovation Management. 12(4): 655-676.

Michael, L., 2008. Introduction of an Evaluation Tool to Predict the Probability of Success of Companies: The Innovativeness, Capabilities and Potential Model (ICP). Journal of Technology: Management and Innovation. 4(1): 33-47.

Muffatto, Moreno, and Roveda, Marco. 2002. Product Architecture and Platforms: A Conceptual Framework. International Journal of Technology Management. 24(2): 1-16.

Rasli A. 2006. Data Analysis and Beyond: A Practical Guide for PostGraduate Social Scientists. Penerbit UTM, Skudai, Malaysia.

Rusinko, Cathy A. 1999 . Exploring the use of Design-Manufacturing Integration (DMI) to Facilitate Product Development: A Test of Some Practices. IEEE Transactions on Engineering Management. 46(1): 5671.

Rudha B., Ragu A. and Xueshu S. 2000. The Relevance of Concurrent Engineering in Industrial Technology Programs. Journal of Industrial Technology. 16: 2-5.

Shenhar, A.J, Tishler, A., Dvir, D.,Lipovetsky, S. and Lechler, T. 2002. Refining the Search for Project Success Factors: A Multivariate, Typological Approach. R\&D Management Journal. 32(2): 111-126.

Smith, R. P. 1998. Deciding between Sequential and Concurrent Tasks in Engineering Design Concurrent Engineering. Sage Journals. 6(1): 16

Terrell J. 2006. Scoring the HNQOL Instrument. The Laryngoscope. 110(2): $620-626$.

Ulrich, Karl. 1995. The Role of Product Architecture in Manufacturing Firm. Research Policy. 24: 419-440.

Zhang J.C., Anthony D.B. and H. Scott. 2009. Product Development Strategy, Product Innovation Performance, and the Mediating Role of Knowledge Utilization: Evidence from Subsidiaries in China. Journal of International Marketing. 17(3): 42-58. 